\title{
Effects of Cyclone 'Joy' on nearshore coral communities of the Great Barrier Reef
}

\author{
R. Van Woesik ${ }^{1, *}$, L. M. De Vantier ${ }^{2}$, J. S. Glazebrook ${ }^{3}$ \\ ${ }^{1}$ Department of Marine Sciences, University of the Ryukyus, Senbaru 1, Nishihara, Okinawa 903-01, Japan \\ ${ }^{2}$ Australian Institute of Marine Science, PMB 3, Townsville MC, Queensland 4810, Australia \\ ${ }^{3}$ Department of Biomedical and Tropical Veterinary Sciences, James Cook University of North Queensland, Townsville, \\ Queensland 4811, Australia
}

\begin{abstract}
The rain associated with tropical Cyclone 'Joy', in late 1990 and early 1991, led to the third largest recorded flood in central Queensland. Australia. This study examined the effects of floodwaters on nearshore coral communities, in 3 regions of the Great Barrier Reef. The Keppel Island reefs $\left(23^{\circ} 10^{\prime} \mathrm{S}\right)$ were affected by extreme floodwaters which damaged corals to an average depth of $1.3 \mathrm{~m}$ below low water datum. Mortality was highest for shallow Acropora spp. and pocilloporids; faviids were most tolerant. The most widespread effect on deeper colonies of Acropora spp. was gross swelling and lysis of the epidermal cells and loss of zooxanthellae from the gastrodermis (bleaching). Shallow

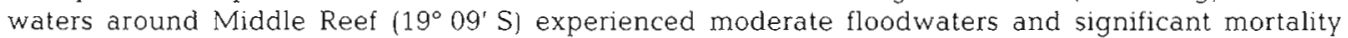
occurred to colonies of Acropora spp; other corals were not damaged. The Whitsunday Island reefs $\left(20^{\circ} 20^{\prime}\right.$ S) were subjected to minor floodwaters and shallow corals suffered little damage; however deep-water pocilloporids died, possibly because of low incident light during the tropical depression.
\end{abstract}

KEY WORDS: Cyclones Floods - Coral damage

\section{INTRODUCTION}

Tropical storms, such as cyclones, hurricanes and typhoons, are among the most severe physical disturbances to affect coral reefs (Ball et al. 1967, Stoddart 1969, Woodley et al. 1981, Harmelin-Vivien 1994). Effects may include the removal of reef matrix, scouring and fragmentation (Van Woesik et al. 1991, Done 1992) or, once tropical storms make landfall, nearshore salinities may decline dramatically, following intense rainfall and flooding. This can cause coral bleaching (the expulsion of endo-symbiotic zooxanthellae) and can lead to extensive mortality of the shallow reef corals (Hedley 1925, Rainford 1925, Goreau 1964. Glynn 1993 for review). Damage may also result from sediment taken into suspension by storm currents causing sandblasting and burial of reef organisms (Ball et al. 1967, Hubbard et al. 1991), or through changes in turbidity, decreasing available light and

\footnotetext{
•E-mail: b984138@sci.u-ryukyu.ac.jp
}

increasing the energetic allocation toward the removal of sediment particles (Rogers 1983).

In mid-December 1990, an intense low pressure system developed in the Coral Sea off the North Queensland coast, Australia (15 ${ }^{\circ}$ S) (Fig. 1). On 19 December Cyclone 'Joy' (barometric pressure of $995 \mathrm{hPa}$ ) entered the Great Barrier Reef province. Its minimum central pressure dropped to $940 \mathrm{hPa}$ on 23 December while it was located approximately $100 \mathrm{~km}$ east of Cairns $\left(16^{\circ} 40^{\prime} \mathrm{S}, 146^{\circ} 30^{\prime} \mathrm{E}\right)$. Wind gusts at times exceeded $200 \mathrm{~km} \mathrm{~h}^{-1}$. For the next $3 \mathrm{~d}$ the cyclone weakened and moved steadily south, crossing the coast on 26 December near Townsville where it degenerated into a tropical depression.

Rainfall was highest in the region between Prosperine $\left(20^{\circ} \mathrm{S}\right)$ and Rockhampton $\left(23^{\circ} \mathrm{S}\right)$ where over $2000 \mathrm{~mm}$ fell between 23 December and 7 January 1991 (Fig. 1). High rainfall associated with tropical low pressure systems continued to the end of March 1991. This led to extensive flooding of the central Queensland coastal plain. The flood was the third largest in more than 100 years. The effects of the tropical depres- 


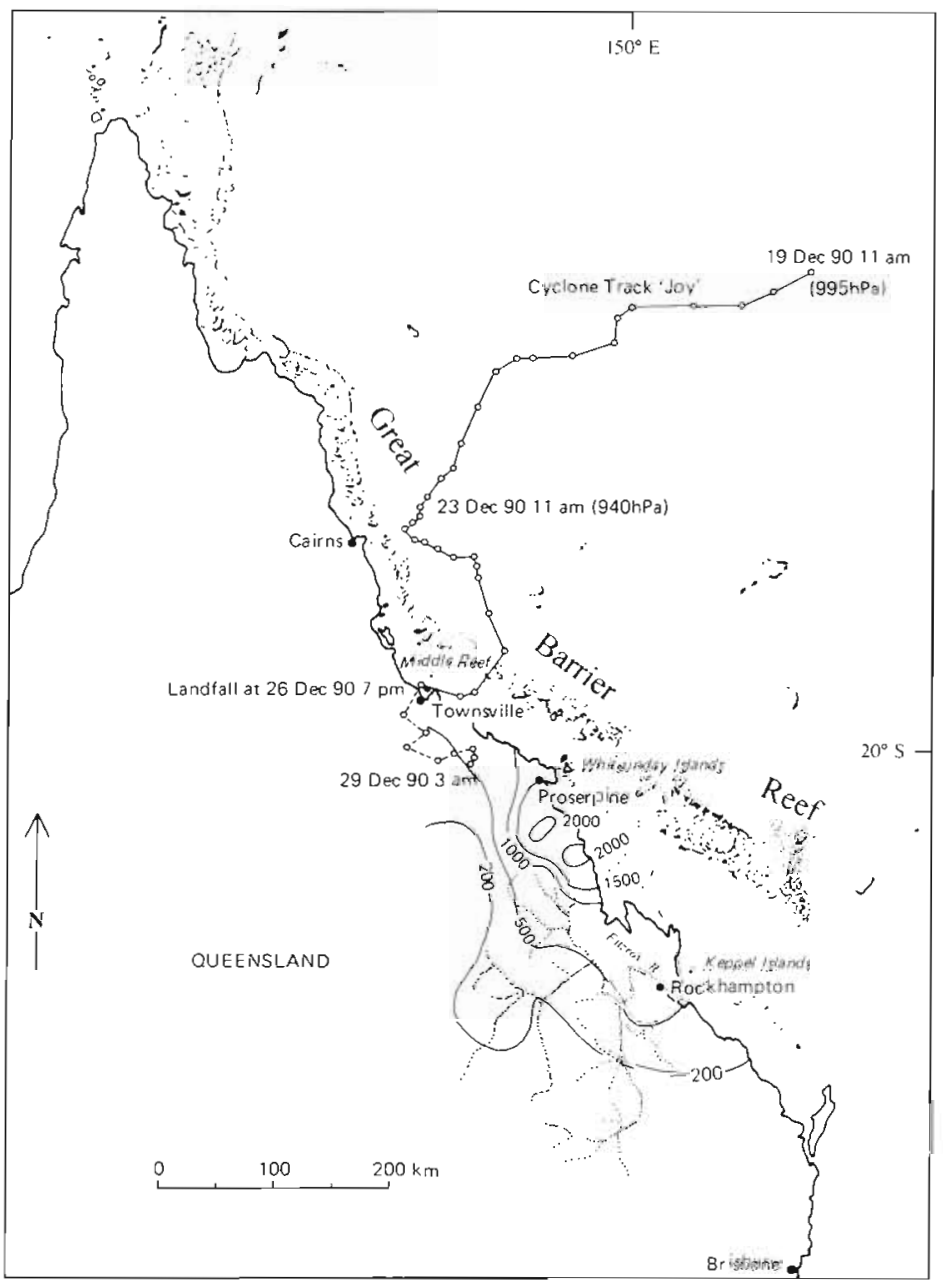

Fig. 1. Map of Queensland, Australia, depicting the track of tropical Cyclone 'Joy' and associated rainfall, where isobars signify $\mathrm{mm}$ of rain from 23 December 1990 to 7 January 1991. The catchment area of the Fitzroy River is depicted by dashed lines

sion on the coral reefs where studied at 3 nearshore locations, the first receiving extreme floodwaters (Keppel Islands), the second moderate floodwaters (Middle Reef), and the third receiving slight surface dilutions (Whitsunday Islands) (Fig. 1).

\section{SITE DESCRIPTION}

Keppel Islands. The Keppel Islands are located at $23^{\circ} 10^{\prime} \mathrm{S}, 150^{\circ} 59^{\prime} \mathrm{E}$ (Fig. 2a), $33 \mathrm{~km}$ from the mouth of the Fitzroy River, which has a catchment area of $140000 \mathrm{~km}^{2}$ (Fig. 1). In December, the river typically discharges an average of $480857 \mathrm{Ml} \mathrm{d}^{-1}$ (mean for the period 1965-1990). During the flood, discharge peaked at $1250000 \mathrm{Ml} \mathrm{d}^{-1}$, causing a $9 \mathrm{~m}$ rise in river height. The first floodwater plume spread over the reefs on 2 January 1991. Salinities were low for $15 \mathrm{~d}$. During the flood peak, salinities around the islands were in the order of 7 to 10 ppt at the surface, 15 to 28 ppt at $3 \mathrm{~m}, 31$ to $34 \mathrm{ppt}$ at $6 \mathrm{~m}$, and 33 to $34 \mathrm{ppt}$ at $12 \mathrm{~m}$ (Brodie \& Mitchell 1992).

Middle Reef. Middle Reef is located in Cleveland Bay, $19^{\circ} 09^{\prime} \mathrm{S}, 146^{\circ} 50^{\prime} \mathrm{E}$, approximately $4 \mathrm{~km}$ offshore from Townsville (Fig. 2b). The Ross River, with a catchment area of $1815 \mathrm{~km}^{2}$, discharges directly into Cleveland Bay. Discharge from Ross River peaked in mid-February at $31873 \mathrm{Ml} \mathrm{d}^{-1}$, averaging at $15000 \mathrm{Ml} \mathrm{d}^{-1}$ for January and February. On 8 and 12 February 1991, surface salinity was $20 \mathrm{ppt}$ and 20.5 ppt at $2.5 \mathrm{~m}$ (Great Barrier Reef Aquarium, M. Townsend pers. comm.).

Whitsunday Islands. The Whitsunday Islands are located $20 \mathrm{~km}$ from the mainland at $20^{\circ} 20^{\prime} \mathrm{S}$ and $148^{\circ} 57^{\prime} \mathrm{E}$ (Fig. 2c). The islands were not influenced by direct river runoff. Although the Proserpine River flows into Repulse Bay, immediately to the south of the Whitsunday Islands, the construction of a large dam $57.7 \mathrm{~km}$ up river (completed in December 1990, just prior to the heavy rains) precluded substantial river runoff (dam catchment area $260 \mathrm{~km}^{2}$, holding capacity $500000 \mathrm{Ml}$ ). Therefore the Whitsunday reefs were subjected to only direct rainfall and localised runoff.

\section{METHODS}

Keppel Islands. A total of 8 fixed sites were established with steel pins on the reef edge, between low water datum and $2 \mathrm{~m}$, in October 1989 (Fig. 2a). At least 3 compass bearings were taken from prominent headlands nearby to facilitate site relocation. Each site measured $20 \times 10 \mathrm{~m}$ with the long axis parallel to the reef crest. The size, identity and abundance of all corals were recorded by subdividing each site into $5 \times 5 \mathrm{~m}$ plots and allocating a size class to each colony based on maximum diameter class $1 \cdot 1$ to $10 \mathrm{~cm}$; class 2: 11 to $50 \mathrm{~cm}$; class $3: 51$ to $100 \mathrm{~cm}$; class 4. 101 to $300 \mathrm{~cm}$; class $5:>301 \mathrm{~cm}$. Sites were re-examined in February 1991 (by RVW). Each site was searched systematically for corals that exhibited bleaching and/or partial or total colony mortality. Colony depth (relative to low water datum) and the level of bleaching (partial or total) was recorded.

Histopathology. Terminal polyps from 10 partially bleached colonies $(5$ Acropora formosa, $2 \mathrm{~A}$. secale, 1 A. latistella, 1 Pocillopora damicornis and 1 Seriato- 

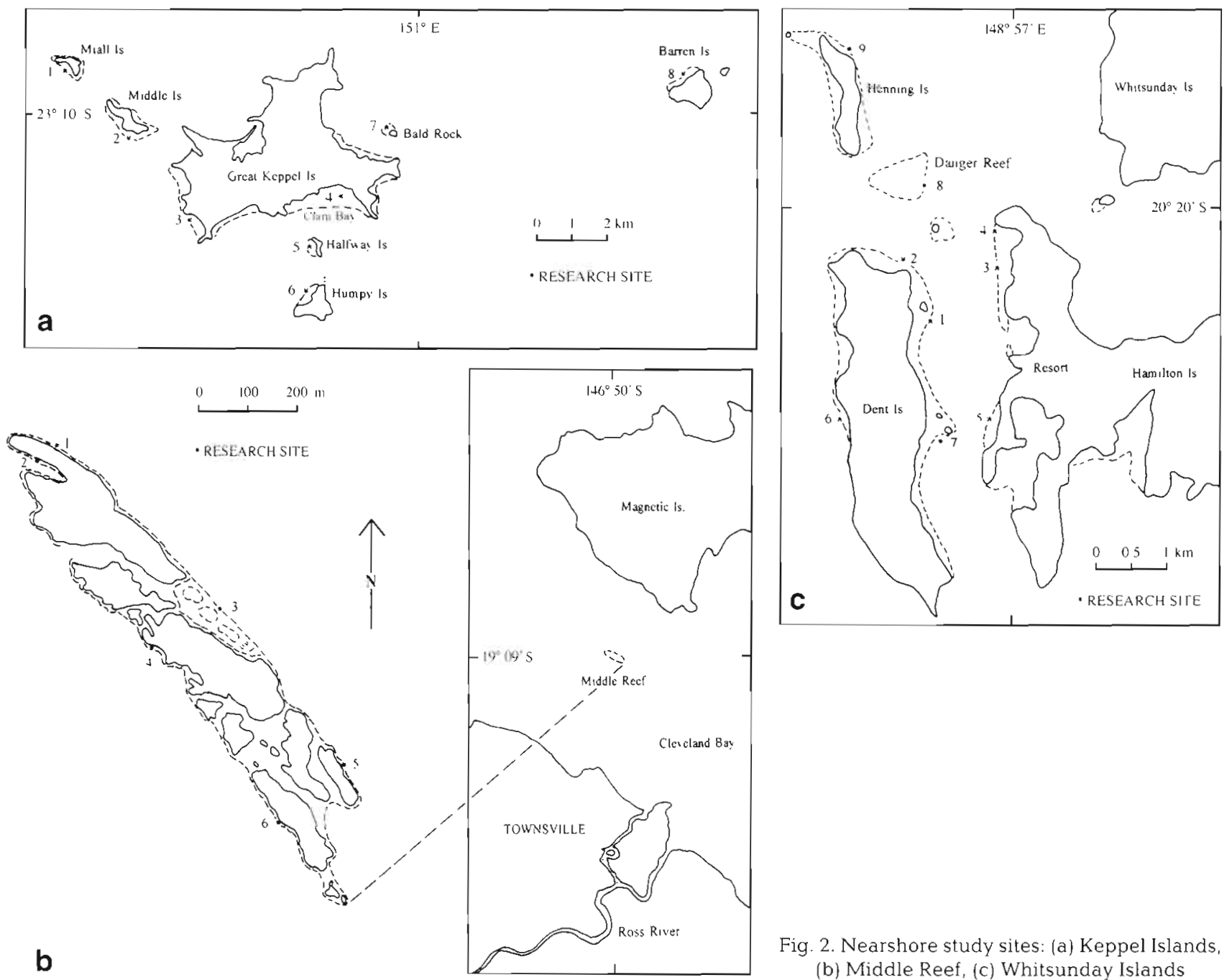

Fig. 2. Nearshore study sites: (a) Keppel Islands, (b) Middle Reef, (c) Whitsunday Islands

pora hystrix) were collected from 2 leeward locations in the Keppel Islands (Clam Bay and Barren Island) in February 1991 at depths ranging from 1 to $6 \mathrm{~m}$. With material intended for histology, an attempt was made to sample the border between normal and bleached tissue. All tissues were fixed in $10 \%$ seawater/formalin in the field and decalcified with formic acid $(0.5$ to $5 \%)$ over a period of several weeks in the laboratory. The remaining soft tissues were embedded in paraffin wax, cut to a thickness of 5 to $6 \mu \mathrm{m}$ and stained with Haematoxylin and Eosin, Periodic Acid Schiff and Trichome (by JSG).

Middle Reei. A total of 6 fixed sites were established with steel pins in July 1990 (Fig. 2b). Each site measured $20 \times 8 \mathrm{~m}$. The $20 \mathrm{~m}$ central axis was placed parallel to the reef crest at $2 \mathrm{~m}$ below low water datum (LWD). In order to calculate estimates of coral cover, 6 haphazardly positioned $20 \mathrm{~m}$ line transects were laid and the intercepts of coral species and other benthos were recorded. All sites were resurveyed after the floods, in June 1991. Mean percent cover estimates were used for comparative analyses after an arcsin transformation. Two-way analysis of variance (ANOVA) was used to determine whether changes had occurred on Middle Reef, using the within subgroups variance as the error mean square.

Whitsunday Islands. A monitoring program was initiated in November 1990 for the eastern Whitsunday Islands (Fig. 2c). A total of 9 sites, on 4 islands, were surveyed for coral abundance and composition using the line transect intercept technique, as for Middle Reef. Sites measured $80 \times 10 \mathrm{~m}$ with the long axis parallel to the reef crest. Four replicate $20 \mathrm{~m}$ line transects were laid, almost contiguously, at each of 4 depths; $0 \mathrm{~m}$ LWD (reef flat), 3,6, and $10 \mathrm{~m}$. These depths were chosen to encompass the 4 major habitats identified by a pilot study. Sites were not marked with steel pins but were relocated to within $50 \mathrm{~m}$ of the original positions, using compass bearings off prominent headlands (RVW pers. obs.). All sites were resur- 
veyed in May 1991. Changes in total coral cover were analysed via a 3 -factor ANOVA, with the 3 main effects fixed, following the fixed factor model in Sokal \& Rohlf (1995). Calculations were undertaken on total length of each taxa per transect, transformed to $\log _{10}(x+1)$.

\section{RESULTS}

\section{Keppel Islands}

Leeward reefs supported large stands of arborescent Acropora species (A. formosa, A. microphthalma), colonies of $A$. millepora, and some faviid and Porites spp. Zonation was indistinct and slopes were primarily covered in monospecific stands. Coral cover was high at most sites ( $\bar{x} 54.3 \%$, SE $9.9 \%)$, particularly at Site 2 (Middle Island), supporting $94 \%$ coral cover, principally Acropora formosa. In contrast, the reef at Site 6 (Humpy Island) supported $19 \%$ cover. Windward reefs supported more species than leeward reefs (Van Woesik 1991).

Mortality after the flood was most apparent on leeward reefs with large reef flats (Fig. 3). In contrast, windward reefs had low $(-5 \%)$ coral mortality. Approximately $85 \%$ of the shallow $(<1.3 \mathrm{~m})$ leeward corals were dead and overgrown by turf algae in early February 1991, suggesting that mortality had taken place shortly after inundation by the first floodwaters. A narrow band of bleached coral was evident between 1.3 and $1.7 \mathrm{~m} \mathrm{LWD}$, and mortality was most pronounced above this depth (Fig. 3). Below this depth most corals were alive, although the reefs usually extended only a further $1.5 \mathrm{~m}$ onto sand, except at Barren Island, a further $7 \mathrm{~km}$ offshore. Barren Island was more akin to a windward reef, supporting narrow reef flats and steep slopes (Fig. 3). This reef showed minor effects, with some shallow Acropora and pocilloporid colonies having bleached.

Mortality was most extensive for Acropora spp., Pocillopora damicornis and Seriatopora hystrix. Colonies of Montipora spp. were partially bleached, appearing more resistant than Acropora spp. to floodwaters. Some survival was apparent above $1.3 \mathrm{~m}$ for the favids Leptastrea, Cyphastrea, Goniastrea, Favites, and Favia spp., the dendrophylliids Turbinaria spp. ( $T$. peltata, $T$. frondens, T. reniformis), the poritids Porites lutea, P. lobata, P. australiensis, and the siderastreids Psammocora contigua and Coscinaraea columna (Table 1).

All specimens collected for histological examination had partial bleaching. Fragments collected from deeper water had more soft tissue intact (particularly Seriatopora hystrix collected from Barren Island). Least affected colonies showed hypertrophy and lysis of the epidermal cells, together with the secretion of large amounts of mucus. More severe damage led to loss of
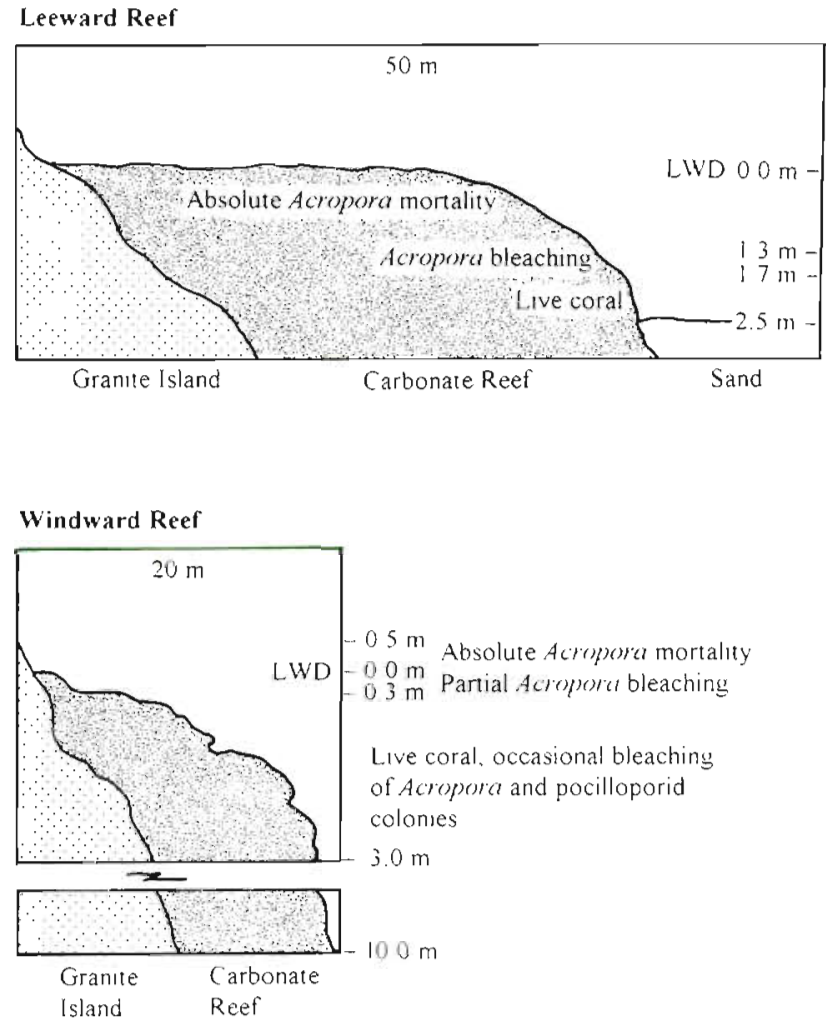

Fig. 3. Vertical profiles of leeward and windward reefs on the Keppel Islands, Queensland, Australia. Flood damage was most extensive on leeward slopes. LWD: Iow water datum

Table 1. Field observations on coral species exposed to floodwaters on Keppel Island reefs above $1.3 \mathrm{~m}$ LWD, February 1991

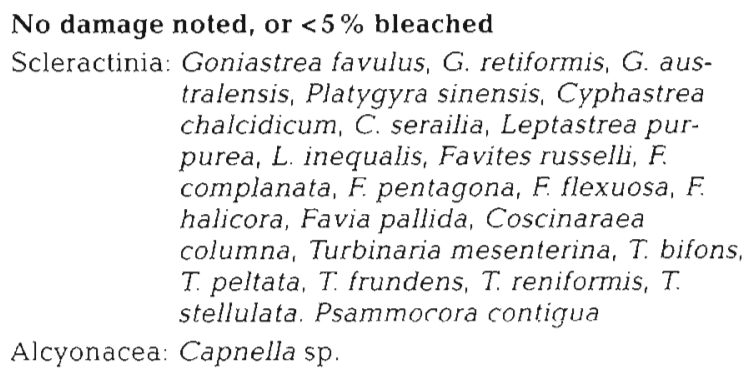

Scleractinia: Goniastrea favulus, G. retiformis, G. australensis, Platygyra sinensis, Cyphastrea chalcidicum, C. serailia, Leptastrea purpurea, L. inequalis, Favites russelli, F. complanata, $F$. pentagona, F flexuosa, $F$. halicora, Favia pallida, Coscinaraea columna, Turbinaria mesenterina, T. bifons, $T$. peltata, $T$. frundens, $T$. reniformis, $T$. stellulata. Psammorora contigua

Alcyonacea: Capnella sp

Partially bleached (and appeared to recover completely)

Scleractinia: Favia favus, Porites australiensis, P. lutea, P. lobata, Goniopora spp., Montipora spp., Galaxea fascicularis, Hydnophora pilosa, Favia rotumana

Alcyonacea: Sarcophyton spp., Efflatournaria spp., Xenia sp., Alcyonium spp.

\section{Totally bleached or dead}

Scleractinia: All Acropora spp. and pocilloporids Alcyonacea: Nephthiids 
zooxanthellae from the gastrodermis, and the formation of bacterial emboli in the subepidermis. The most damaged colonies showed necrosis of the epidermis, gastrodermis, mesogleal filaments and tentacles (Fig. 4). Some resilience to conditions was evident in deeper Acropora spp. by hyperplasia of border areas (i.e. increase in number of cells).

\section{Middle Reef}

Reef slopes were shallow and coral communities extended to 4-5 $\mathrm{m}$. There was little variation in composition with depth. In 1990, hard coral cover was high, ranging from $80 \%$ on the windward edge (east) to $20-40 \%$ on the leeward edge (Table 2). Coral commu-

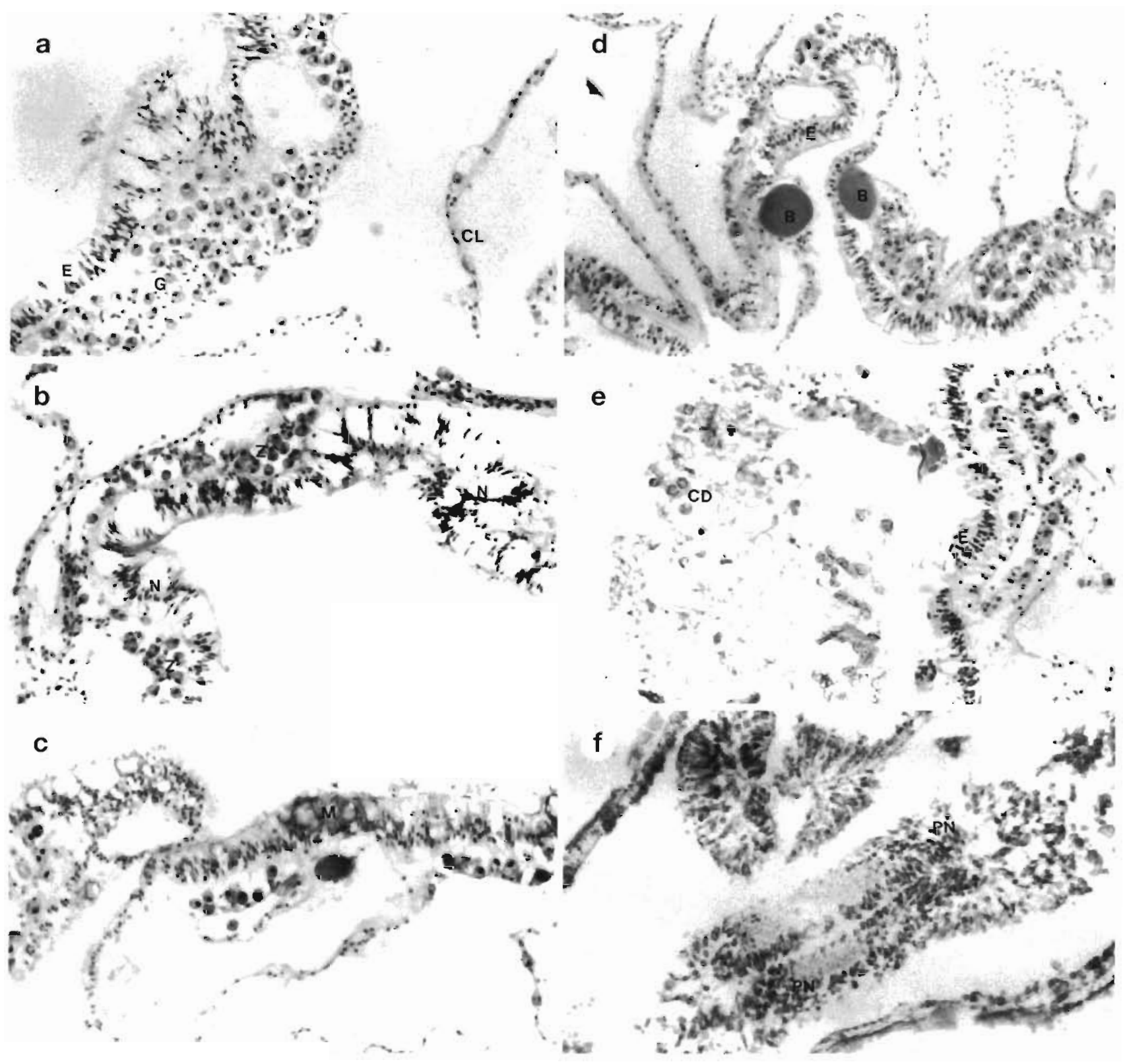

Fig. 4. (a) Cross section of a normal Acropora formosa colony, showing oral ectoderm (E), aboral gastroderm (G) and calicoblastic layer (CL). Mucus secreting cells are interdispersed with tall, columnar epithelium. Zooxanthellae are concentrated in the gastrodermis (stain: H\&E). (b) Hypertrophy of the epidermal layer showing margination of nuclear material ( $N$ ) and the loss of numerous zooxanthellae (Z) from the gastrodermis (H\&E). (c) Mucus (M) in the epidermal/subepidermal layers of a hyposaline-stressed Acropora (Periodic Acid Schiff and Trichome). (d) Ovoid, gram negative, bacterial (B) colonies on the subepidermal region. One colony has breached the integrity of the epithelium (E) and another lies between the epidermis and gastrodermis. Note a lack of inflammatory response $(H \& E)$. (e) Death of a polyp - rupturing of epidermal cells (E) and shedding of mucus and cellular debris (CD) to the external surfaces (H\&E). (f) Advanced decay - necrotic debris consisting of degenerating cell wall and nuclear material. Pyknotic nuclei (PN) resemble dark, basophilic staining bodies (H\&E). All panels $\times 200$ 
nities were composed primarily of fast-growing corals at Sites 1, 2, 3 and 5: Montipora spp. (M. tuberculosa group), Acropora spp. (A. latistella, A. nobilis, A. formosa), Turbinaria reniformis at Site 4 , and Porites spp. at Site 6.

The post-flood survey was conducted 4 mo after the passage of Cyclone 'Joy'. Significant increases in dead coral cover were evident ( $p<0.001$, Table 3a), where an a posteriori Least Significant Difference (LSD) test showed that the mean cover of dead coral was significantly greater after the cyclone, primarily because of the significant mortality in colonies of Acropora spp. (A. latistella, A. tenuis, and A. digitifera) at Sites 1, 2, 3 and 5 (Fig. 5a). However, there was no discernible net change in live coral cover 4 mo after the flooding (Table 3b) because the loss of Acropora spp. was the same as the growth in Montipora spp. between observation periods (Fig. 5b). Nevertheless, shifts in community composition and relative abundances had occurred.

\section{Whitsunday Islands}

Well developed reefs in the eastern Whitsunday Islands supported corals in 4 distinct habitats. (1) The reef flat had low coral cover $\sim 8 \%$ composed of Montipora spp., Turbinaria spp., Pavona varians, Goniastrea spp., Porites spp., Acropora millepora and Acropora valida. (2) The reef crest supported monospecific stands of massive Porites spp., Acropora spp. and Sinularia spp. (soft coral). Coral cover was $\sim 25 \%$. (3) The upper slope, from 3 to $6 \mathrm{~m}$, supported diverse communities (classified as the acroporid/pocilloporid/poritid zone), and a coral cover which ranged from 15 to $65 \%$; (4) The lower slope, from 6 to $10 \mathrm{~m}$, supported pectiniid, mussid and agariciid corals with $\sim 30 \%$ coral cover (Table 4 ).

There was no significant difference in the amount of (total) live coral cover between the observation periods (Table 5a). There was however a significant increase in dead coral cover $(\mathrm{p}<0.0001)$, and a significant $(p<0.0001)$ interaction effect between time and site

Table 2. Change in mean percent coral cover between July 1990 and June 1991, at 6 sites, on Middle Reef, Queensland, Australia. Standard error is given in brackets. - : $0 \%$ coral cover

\begin{tabular}{|c|c|c|c|c|c|c|c|}
\hline & Year & Site 1 & Site 2 & Site 3 & Site 4 & Site 5 & Site 6 \\
\hline Hard coral cover & $\begin{array}{l}1990 \\
1991\end{array}$ & $\begin{array}{l}45.4(4.3) \\
39.0(11.8)\end{array}$ & $\begin{array}{l}58.2(18.5) \\
30.5(11.4)\end{array}$ & $\begin{array}{l}82.8(9.6) \\
40.5(7.0)\end{array}$ & $\begin{array}{l}37.5(10.0) \\
30.2(15.9)\end{array}$ & $\begin{array}{l}34.4(12.2) \\
30.2(7.4)\end{array}$ & $\begin{array}{r}17.9(9.2) \\
9.3(1.9)\end{array}$ \\
\hline Dead coral cover & $\begin{array}{l}1990 \\
1991\end{array}$ & $\begin{array}{l}0.1(0.5) \\
6.3(3.2)\end{array}$ & $\begin{array}{l}2.4(0.7) \\
5.8(1.6)\end{array}$ & $\begin{array}{l}2.8(1.1) \\
9.2(2.3)\end{array}$ & $\begin{array}{l}1.1(0.4) \\
0.8(0.3)\end{array}$ & $\begin{array}{l}0.9(0.5) \\
4.0(1.3)\end{array}$ & $\begin{array}{l}0.3(02) \\
3.8(1.5)\end{array}$ \\
\hline Soft coral cover & $\begin{array}{l}1990 \\
1991\end{array}$ & $\begin{array}{l}4.4(2.2) \\
4.3(2.4)\end{array}$ & $\begin{array}{l}0.7(0.2) \\
2.8(1.3)\end{array}$ & $\begin{array}{l}1.0(0.6) \\
0.3(0.3)\end{array}$ & $\begin{array}{l}3.1(0.5) \\
3.6(0.7)\end{array}$ & $\begin{array}{l}0.2(0.2) \\
0.8(0.3)\end{array}$ & $\begin{array}{l}1.2(0.5) \\
0.8(0.4)\end{array}$ \\
\hline \multicolumn{8}{|l|}{ Family } \\
\hline Acroporidae & $\begin{array}{l}1990 \\
1991\end{array}$ & $\begin{array}{l}41.3(2.3) \\
47.9(4.0)\end{array}$ & $\begin{array}{l}51.8(9.4) \\
55.7(8.3)\end{array}$ & $\begin{array}{l}80.1(4.7) \\
76.1(3.7)\end{array}$ & $\begin{array}{l}7.0(1.8) \\
7.2(2.0)\end{array}$ & $\begin{array}{l}30.3(4.5) \\
32.7(3.4)\end{array}$ & $\begin{array}{l}1.1(0.5) \\
1.0(1.0)\end{array}$ \\
\hline Faviidae & $\begin{array}{l}1990 \\
1991\end{array}$ & $\begin{array}{l}1.7(0.7) \\
1.9(0.4)\end{array}$ & $\begin{array}{l}1.0(0.4) \\
0.6(0.3)\end{array}$ & $\begin{array}{c}0.1(0.1) \\
-\end{array}$ & $\begin{array}{l}1.2(0.2) \\
0.7(0.3)\end{array}$ & $\begin{array}{l}1.0(0.4) \\
0.9(0.4)\end{array}$ & $\begin{array}{l}1.0(0.4) \\
0.6(0.2)\end{array}$ \\
\hline Dendrophylliidae & $\begin{array}{l}1990 \\
1991\end{array}$ & $\begin{array}{l}1.5(0.2) \\
2.4(0.9)\end{array}$ & $\begin{array}{l}1.5(0.8) \\
0.9(0.4)\end{array}$ & $\begin{array}{l}1.8(0.9) \\
2.6(1.2)\end{array}$ & $\begin{array}{l}27.1(3.3) \\
25.7(4.2)\end{array}$ & $\begin{array}{l}2.5(0.9) \\
1.7(0.7)\end{array}$ & $\begin{array}{l}3.6(1.1) \\
2.9(0.9)\end{array}$ \\
\hline Poritidae & $\begin{array}{l}1990 \\
1991\end{array}$ & $\begin{array}{l}0.6(0.3) \\
1.0(0.3)\end{array}$ & $\begin{array}{l}0.6(0.3) \\
0.5(0.4)\end{array}$ & $\begin{array}{l}- \\
-\end{array}$ & $\begin{array}{l}0.5(0.4) \\
1.2(0.3)\end{array}$ & $\begin{array}{l}0.1(0.1) \\
0.6(0.3)\end{array}$ & $\begin{array}{r}10.6(1.9) \\
6.9(1.4)\end{array}$ \\
\hline Mussidae & $\begin{array}{l}1990 \\
1991\end{array}$ & $\overline{-}-\overline{1}(0.1)$ & $\begin{array}{l}- \\
-\end{array}$ & - & $\begin{array}{l}- \\
-\end{array}$ & $\begin{array}{l}- \\
-\end{array}$ & $\begin{array}{l}0.2(0.2) \\
0.2(0.2)\end{array}$ \\
\hline Oculinidae & $\begin{array}{l}1990 \\
1991\end{array}$ & $\begin{array}{l}0.3(0.2) \\
0.7(0.4)\end{array}$ & $\begin{array}{l}0.1(0.1) \\
0.2(0.2)\end{array}$ & $0 . \overline{2}(0.1)$ & $\begin{array}{c}0.1(0.1) \\
-\end{array}$ & $\begin{array}{l}0.1(0.1) \\
0.3(0.2)\end{array}$ & $\begin{array}{l}- \\
-\end{array}$ \\
\hline Siderastreidae & $\begin{array}{l}1990 \\
1991\end{array}$ & $\begin{array}{l}- \\
-\end{array}$ & $\begin{array}{l}- \\
-\end{array}$ & - & $\begin{array}{l}0.8(0.5) \\
0.7(0.2)\end{array}$ & $\begin{array}{l}0.1(0.1) \\
0.3(0.3)\end{array}$ & $\begin{array}{l}0.3(0.3) \\
0.2(0.1)\end{array}$ \\
\hline Agariciidae & $\begin{array}{l}1990 \\
1991\end{array}$ & $\begin{array}{l}- \\
-\end{array}$ & $\begin{array}{l}1.0(0.8) \\
1.1(0.9)\end{array}$ & $\begin{array}{l}- \\
-\end{array}$ & $\begin{array}{l}1.1(1.1) \\
2.5(2.5)\end{array}$ & $0 . \overline{1}(0.1)$ & $\begin{array}{l}- \\
-\end{array}$ \\
\hline Pectiniidae & $\begin{array}{l}1990 \\
1991\end{array}$ & $\begin{array}{l}0.4(0.4) \\
0.6(0.6)\end{array}$ & $\begin{array}{l}0.8(0.4) \\
0.1(0.1)\end{array}$ & $\begin{array}{l}- \\
-\end{array}$ & - & $0 . \overline{2}(0.1)$ & $\begin{array}{c}0.6(0.6) \\
-\end{array}$ \\
\hline Fungiidae & $\begin{array}{l}1990 \\
1991\end{array}$ & $\stackrel{-}{0.1(0.1)}$ & $\begin{array}{l}0.6(0.4) \\
0.2(0.1)\end{array}$ & $\begin{array}{l}0.2(0.1) \\
0.1(0.1)\end{array}$ & $\begin{array}{l}- \\
-\end{array}$ & $0.2^{-}(0.1)$ & $\begin{array}{l}- \\
-\end{array}$ \\
\hline Merulinidae & $\begin{array}{l}1990 \\
1991\end{array}$ & $\begin{array}{l}- \\
-\end{array}$ & $\begin{array}{l}09(0.5) \\
0.5(0.4)\end{array}$ & $\begin{array}{l}0.5(0.5) \\
0.4(0.3)\end{array}$ & $0 . \overline{2}(0.2)$ & $\begin{array}{l}- \\
-\end{array}$ & - \\
\hline Pocilloporidae & $\begin{array}{l}1990 \\
1991\end{array}$ & $\stackrel{-}{0.1(0.1)}$ & $\stackrel{-}{0.1(0.1)}$ & $\begin{array}{l}0.1(0.1) \\
0.1(0.1)\end{array}$ & $\begin{array}{l}- \\
-\end{array}$ & $\begin{array}{l}0.2(0.2) \\
0.2(0.2)\end{array}$ & $\begin{array}{l}0.8(0.4) \\
0.4(0.3)\end{array}$ \\
\hline
\end{tabular}


Table 3. Two-way analysis of variance (ANOVA) for changes in (a) dead coral and (b) live coral cover on Middle Reef before and after the 1991 floods

\begin{tabular}{|lrrrc|}
\hline Source of variation & df & MS & F-value & $\mathrm{p}$ \\
\hline (a) Dead coral & & & & \\
Time (Factor A) & 1 & 0.0231 & 18.61 & 0.0001 \\
Site (Factor B) & 5 & 0.0038 & 3.06 & 0.0159 \\
A B B & 5 & 0.0016 & 1.31 & 0.2702 \\
Error & 60 & 0.0012 & & \\
(b) Live coral & & & & \\
Time (Factor A) & 1 & 0.0007 & 0.04 & 0.8494 \\
Site (Factor B) & 5 & 0.9229 & 49.69 & 0.0001 \\
A $\times$ B & 5 & 0.0127 & 0.69 & 0.6385 \\
Error & 60 & 0.0186 & & \\
\hline
\end{tabular}

(Table $5 b$ ). The latter suggests mortality between the observation periods was strongly dependent on location. Although there was no significant overall mortality recorded for pocilloporids (Table $5 c$ ), when Sites 3 and 4 were analysed separately there was a significant decline in pocilloporid cover between observation periods $(F=6.70, \mathrm{df}=1,63, p=0.013 ;$ Fig. 6). Mortality was highest in Seriatopora hystrix, the needle-like pocilloporid, which was dominant on the lower slopes. No significant changes were detected for other coral families i.e. Acroporidae, Poritidae, Mussidae, Pectiniidae, Faviidae and soft corals, although their distribution patterns varied among habitats (Table 4).

\section{DISCUSSION}

The Fitzroy River plume flowed predominantly northeast over the denser saline waters and became diluted with increased distance from the rivermouth
Table 5. Three-way analysis of variance (ANOVA) for changes in live coral, dead coral and pocilloporidae corals in the Whitsunday Islands before and after the floods, where all 3 main effects are fixed

\begin{tabular}{|c|c|c|c|c|}
\hline Source of variation & $\mathrm{df}$ & MS & $F$-value & $\mathrm{p}$ \\
\hline \multicolumn{5}{|l|}{ (a) Live coral } \\
\hline Time (Factor A) & 1 & 0.2908 & 1.99 & 0.1596 \\
\hline Site (Factor B) & 8 & 0.8715 & 5.97 & 0.0001 \\
\hline Habitat (Factor C) & 3 & 18.510 & 126.78 & 0.0001 \\
\hline \multicolumn{5}{|l|}{ Interactions } \\
\hline $\mathrm{A} \times \mathrm{B}$ & 8 & 0.2358 & 1.61 & 0.1232 \\
\hline $\mathrm{A} \times \mathrm{C}$ & 3 & 0.0407 & 0.28 & 0.8415 \\
\hline $\mathrm{B} \times \mathrm{C}$ & 24 & 0.4394 & 3.01 & 0.0001 \\
\hline$A \times B \times C$ & 24 & 0.2743 & 1.88 & 0.0101 \\
\hline Error & 216 & 0.1460 & & \\
\hline \multicolumn{5}{|l|}{ (b) Dead coral } \\
\hline Time (Factor A) & 1 & 47.461 & 79.84 & 0.0001 \\
\hline Site (Factor B) & 8 & 5.5671 & 9.37 & 0.0001 \\
\hline Habitat (Factor C) & 3 & 3.6030 & 6.06 & 0.0006 \\
\hline \multicolumn{5}{|l|}{ Interactions } \\
\hline$A \times B$ & 8 & 4.6704 & 7.86 & 0.0001 \\
\hline$A \times C$ & 3 & 1.9137 & 3.22 & 0.0234 \\
\hline $\mathrm{B} \times \mathrm{C}$ & 24 & 1.1026 & 1.85 & 0.0114 \\
\hline $\mathrm{A} \times \mathrm{B} \times \mathrm{C}$ & 24 & 1.1907 & 2.00 & 0.0050 \\
\hline Error & 216 & 0.5944 & & \\
\hline \multicolumn{5}{|l|}{ (c) Pocilloporidae } \\
\hline Time (Factor A) & 1 & 0.8285 & 0.82 & 0.3667 \\
\hline Site (Factor B) & 8 & 17.624 & 17.41 & 0.0001 \\
\hline Habitat (Factor C) & 3 & 18.550 & 18.32 & 0.0001 \\
\hline \multicolumn{5}{|l|}{ Interactions } \\
\hline$A \times B$ & 8 & 1.527 & 1.51 & 0.1549 \\
\hline$A \times C$ & 3 & 0.5037 & 0.50 & 0.6884 \\
\hline $\mathrm{B} \times \mathrm{C}$ & 24 & 5.1338 & 5.07 & 0.0001 \\
\hline $\mathrm{A} \times \mathrm{B} \times \mathrm{C}$ & 24 & 1.7077 & 1.69 & 0.0276 \\
\hline Error & 216 & 1.0124 & & \\
\hline
\end{tabular}

Table 4 . Change in mean percent coral cover ( $S D$ in brackets) between November 1990 and May 1991, at 4 depths in the Whitsunday Islands, Queensland, Australia. Sixteen $20 \mathrm{~m}$ line transects were measured at each depth. -: $0 \%$ coral cover

\begin{tabular}{|lccccc|}
\hline Family & Year & Reef flat & Reef crest & $\begin{array}{c}\text { Upper slope } \\
<6 \mathrm{~m}\end{array}$ & $\begin{array}{c}\text { Lower slope } \\
6-12 \mathrm{~m}\end{array}$ \\
\hline Acroporidae & 1990 & $2.1(2.0)$ & $15.8(17.3)$ & $10.4(11.5)$ & $5.3(3.0)$ \\
& 1991 & $4.8(4.6)$ & $11.0(14.3)$ & $12.4(12.6)$ & $4.8(3.0)$ \\
Pocilloporidae & 1990 & $0.7(1.1)$ & $2.1(2.3)$ & $8.7(15.3)$ & $7.9(11.9)$ \\
& 1991 & $0.5(0.6)$ & $1.8(1.7)$ & $5.5(6.2)$ & $1.8(2.5)$ \\
Faviidae & 1990 & $0.9(0.4)$ & $2.3(2.3)$ & $3.2(2.2)$ & $2.7(1.7)$ \\
& 1991 & $0.9(0.6)$ & $1.7(1.6)$ & $2.8(2.9)$ & $3.1(2.6)$ \\
Poritidae & 1990 & $1.3(0.9)$ & $15.1(14.6)$ & $9.6(10.6)$ & $7.9(7.9)$ \\
& 1991 & $3.5(6.4)$ & $14.4(14.7)$ & $12.4(10.9)$ & $9.7(10.0)$ \\
Pectiniidae & 1990 & - & $1.3(1.6)$ & $3.0(3.1)$ & $5.3(3.5)$ \\
& 1991 & $0.2(0.7)$ & $1.3(1.7)$ & $2.5(2.7)$ & $5.7(4.9)$ \\
Mussidae & 1990 & $0.3(0.4)$ & $0.8(0.9)$ & $0.8(0.6)$ & $0.5(0.7)$ \\
& 1991 & $0.3(0.3)$ & $0.7(1.0)$ & $0.8(0.7)$ & $1.1(1.0)$ \\
\hline
\end{tabular}

(Brodie \& Mitchell 1992). River plumes are usually restricted to nearshore waters of the Great Barrier Reef (Wolanski \& van Senden 1983, King \& Wolanski 1991). Extensive coral mortality was apparent on leeward reefs of the Keppel Islands. Windward reefs were only marginally affected. Shallow Acropora spp. (A. formosa, A. microphthalma, A. latistella, A. millepora, A. valida) and pocilloporids (Pocillopora damicomis, Seriatopora hystrix) were most susceptible. Coral mortality did not extend beyond $1.7 \mathrm{~m}$.

Coral mortality may have resulted from either one or a combination of effects, including low salinity (Rainford 1925, Hoegh-Gulberg \& Smith 

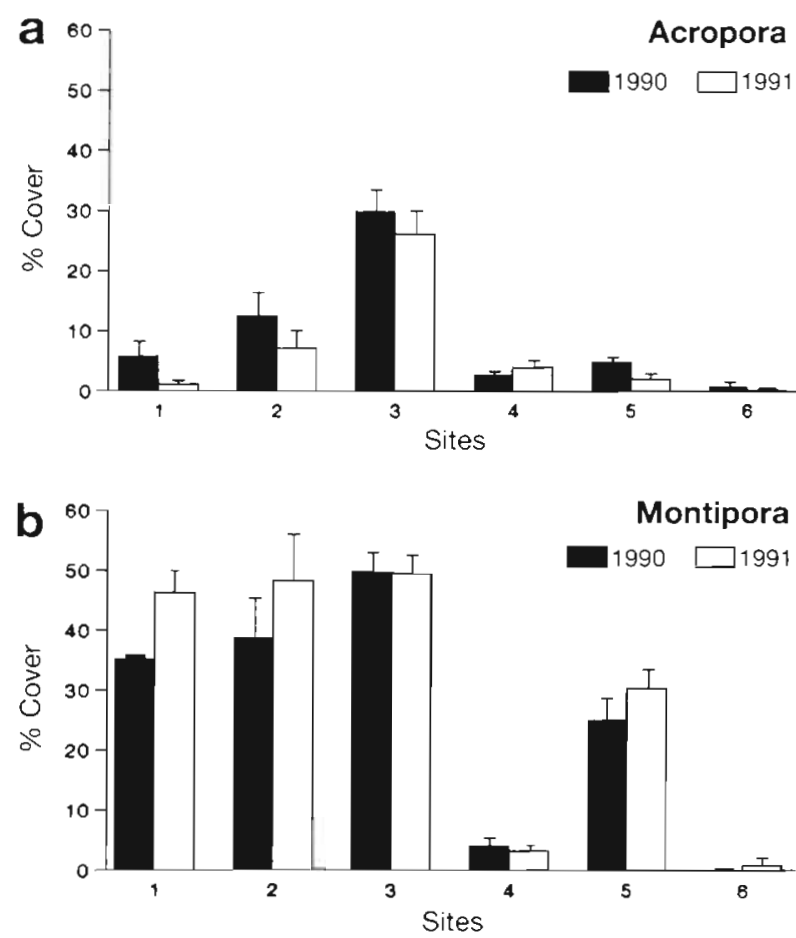

Fig. 5. (a) Percentage cover of Acropora spp. in 1990 and 1991. for 6 sites on Middle Reef, Queensland, Australia. (b) Percentage cover of Montipora spp. in 1990 and 1991, for 6 sites on Middle Reef

1989), sedimentation (Hubbard et al. 1991, StaffordSmith 1993), sandblasting (Ball et al. 1967), or decreases in ambient light (Rogers 1979). The field collections and subsequent histopathological examinations of Acropora and pocilloporid species from the Keppel Islands showed that the most acute and widespread effect of the floodwater was gross swelling and lysis of the epidermal cells. The absence of an infectious agent and inflammation indicated that damage was most likely a hypo-osmotic effect of low salinities. The production of large amounts of mucus and expulsion of zooxanthellae from the gastrodermis were less-

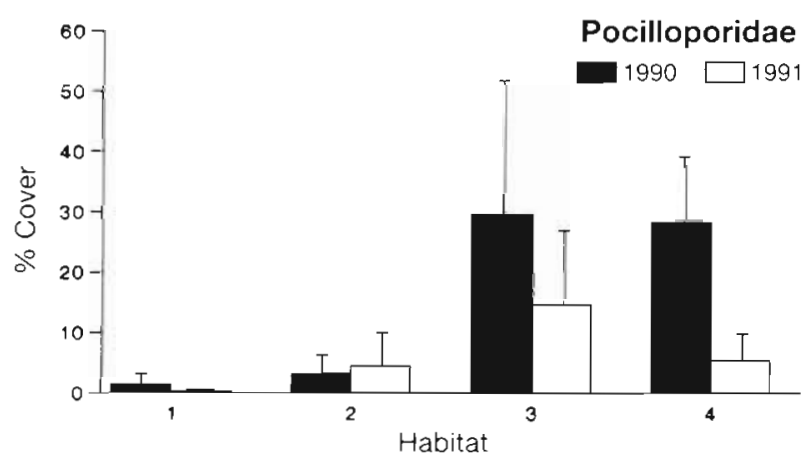

Fig. 6. Percentage cover of pocilloporid colonies at 4 habitats, (1) reef flat, (2) reef crest, (3) upper slope $<6 \mathrm{~m}$, (4) lower slope 6 to $12 \mathrm{~m}$, in 1990 and 1991. Sites 3 and 4, Whitsunday Islands specific indicators of stress which could have been exacerbated by heavy sediment load and low light conditions in the water column (Rogers 1979).

Necrosis of important structural components such as mesogleal filaments and tentacles was the direct result of lysis, leaving behind cellular debris and pyknotic nuclei. The mechanism by which bacterial emboli developed in the subepidermis was unknown, although these have been reported in anemones Ceriantheopsis americanus exposed to dredge spoil (Peters \& Yevich 1989). The ability of corals to recover from medium term exposure to floodwaters, was evident by the presence of hyperplasia in the border tissues. What cellular processes prevented stress in faviids is unknown; however, the reduced exposure of the body wall to the external environment, largely a consequence of their morphology, may increase resistance. Previously, Muthiga \& Szmant (1987) reported on the resistance of the Atlantic species Siderastrea siderea to reduced salinities, a species similar to many faviids. These authors suggested that polyps retract in response to environmental extremes (not only in hypo-saline conditions), to produce 'blanching'. This term was recently coined by Brown \& Ogden (1993) to describe (temporary) visible paling without loss of photosynethic pigments or zooxanthellae (Brown et al. 1994).

Shallow communities on Middle Reef exhibited mortality only in colonies of Acropora spp. (A. latistella, A. valida, $A$. digitifera and $A$. tenuis). Pocilloporids were rare. No net change in coral cover was evident, although a shift in community composition occurred. Cover of Montipora spp. had increased considerably between sampling periods, compensating for the loss of Acropora spp.

In the Whitsunday Islands, the upper slope communities showed no detectable change in coral cover or signs of necrosis. Deep water pocilloporids, specifically Seriatopora hystrix, were most affected and were observed undergoing necrosis in situ during the tropical depression (M. Stafford-Smith pers comm.). Analyses of all sites showed no significant (overall) coral mortality; however, significant mortality was apparent when sites with abundant pocilloporid cover were analysed independently. These results emphasize that subtle changes to corals can be masked by the patchy distributions of associated organisms.

The small polyps of Seriatopora hystrix suggest that autotrophy (Porter 1976), via photosynthesis by the endo-symbiont, is the primary source of energy. Respiration rates of Seriatopora hystrix increase as light intensity decreases, implying colony stress (HoeghGulberg \& Smith 1989). Light extinction coefficients $(k)$ are generally high in the Whitsunday Islands $(k=$ 0.410 ; S. Blake pers. comm.) because of the high turbidity characteristic of the area. Further reductions in 
light during the tropical depression were caused by overcast skies and plankton blooms (Brodie \& Mitchell 1992). Long periods of low light on deep reef slopes increase the light extinction coefficient below $5 \%$ surface light, where autotrophs (such as Seriatopora hystrix) may not be able to survive. Other corals, such as mussids and pectiniids, which are more heterotrophic, may have been able to compensate their energy requirements at these depths.

Coral bleaching and mortality have been previously reported from both the Indo-Pacific and Caribbean regions in association with stormwater runoff, varying from minor damage (Orr 1933), to extensive coral bleaching because of moderate floodwater (Goreau 1964), and massive reef mortality during extreme events (Yonge \& Nichools 1931, Goodbody 1961, Jokiel et al. 1993). Mayer (1918) and Jokiel et al. (1993) both reported the susceptibility of species of Montipora and Pocillopora to floodwaters, and Jokiel et al. (1993) noted the unusual resilience of Porites compressa, where apparent death was followed by the subsequent regeneration of tissue. The present study also found intense effects on acroporids and pocilloporids but less severe effects on both Montipora and Porites spp. (Table 1). Porites spp. appeared resistant (as opposed to resilient) to floodwater, as only partial bleaching was observed, from which they recovered in 2 mo (RVW pers. obs.). Notably, Jokiel et al. (1993) reported on Porites compressa, a coral with digitate morphology, whereas the Porites spp. on the Keppel Islands were predominantly massive colonies ( $P$. lutea, $P$. lobata, and $P$ australiensis). Hedley (1925) and Rainford (1925) described the effect of the 1918 flood on the Whitsunday reefs, which was the most extensive flood on record for the area. Both Hedley and Rainford reported absolute coral mortality above 2 to $3 \mathrm{~m}$. Their descriptions are similar to those reported here for the Keppel Islands, although the 1991 effects were less severe and restricted to corals in waters shallower than $1.7 \mathrm{~m}$.

Hypothetically, disturbance events of this nature may allow species that are more resistant to floodwaters, such as Porites spp. and faviids, to dominate the Keppel Island reefs, especially since partially bleached Porites and faviids recovered. However, extensive discharge from the Fitzroy River occurs regularly. A flood of this intensity has a recurrence interval of approximately $50 \mathrm{yr}$, although floods with half the flow rate occur approximately every 8 yr (Bureau of Meteorology Report 1991). A high disturbance frequency may sustain the reef communities at a primary or recovering stage in succession, where opportunist corals, such as Acropora spp., dominate through history. Furthermore, remnant survivors on the lower slopes were Acropora spp., and the southern Great Barrier Reef region is dominated by Acropora spp. (Van Woesik 1991), increasing the likelihood that similar communities will again dominate.

Floods associated with Cyclone 'Joy' caused differential coral mortality and shifts in community composition which were dependent on both the intensity of floodwater discharge and types of coral communities present. Acropora and pocilloporid colonies were most susceptible to the floodwaters and associated conditions. In contrast, colonies with massive morphology generally exhibited only partial bleaching and recovered rapidly. A history of the frequency and intensity of such events may be traced through proxy cues in the skeleton of massive colonies (Isdale 1984, Risk et al. 1992). In a regional context, integrating isotopic stratigraphy studies, from massive corals, with realtime responses of coral communities subjected to extreme events, may allow not only the reconstruction of historical ocean-atmospheric variability but also the turnover frequency of associated communities (Williams \& Bunkley-Williams 1990, Glynn 1993).

Acknowledgements. We thank the Great Barrier Reef Marine Park Authority for funding this research, Tony Ayling for his assistance in the Whitsunday Islands and Andrew Steven for assitance on Middle Reef, Steve Blake for making available light extinction profiles, Sandra van Woesik for editorial comments and graphics and 3 anonymous reviewers whose comments on the manuscript were greatly appreciated. This paper is dedicated to the late Terry Walker for his contribution to marine science.

\section{LITERATURE CITED}

Ball MM, Shinn EA, Stockman KW (1967) The geologic effects of Hurricane Donna in South Florida. J Geol 75 : 583-597

Brodie JE, Mitchell A (1992) Nutrient composition of the January, 1991 Fitzroy River Plume. In: Byron GT (ed) Workshop on the effects of 1991 Floods. Queensland National Parks and Wildlife Service and Great Barrier Reef Marine Park Authority Publ. Workshop Series 17:56-74

Brown BE, Ogden JC (1993) Coral bleaching. Sci Am 268: $44-50$

Brown BE, Le Tissier MDA, Dunne RP (1994) Tissue retraction in the scleractinian coral Coeloseris mayeri, its effect upon coral pigmentation, and preliminary implications for heat balance. Mar Ecol Prog Ser 105:209-218

Bureau of Meteorology Report (1991) Floods associated with severe tropical cyclone Joy, December 1990-January 1991. Bureau of Meterology, Queensland Regional Office, Rockhampton, $\mathrm{p} 11$

Done TJ (1992) Effects of tropical cyclone waves on ecological and geomorphological structures on the Great Barrier Reef. Cont Shelf Res 12:859-872

Glynn PW (1993) Coral reef bleaching: ecological perspectives. Coral Reefs 12:1-17

Goodbody I (1961) Mass mortality of marine fauna following tropical rain. Ecology 42:150-155

Goreau TF (1964) Mass expulsion of zooxanthallae from Jamaican reef communities after Hurricane Flora. Science $145: 383-386$ 
Harmelin-Vivien ML (1994) The effects of storms and cyclones on coral reefs: a review. J coast Res Spec Iss 12: 211-231

Hedley C (1925) The natural destruction of a coral reef. Rep Gr Barrier Reef Comm 1:35-40

Hoegh-Gulberg H, Smith GJ (1989) The effect of sudden changes in temperature, light and salinity on the population density and export of zooxanthellae from the reef corals Stylophora pistillata Esper and Seriatopora hystrix Dana. J exp mar Biol Ecol 129:279-303

Hubbard DK, Parsons KM, Bythell JC, Walker ND (1991) The effects of hurricane Hugo on the reefs and associated environments of St-Croix, US Virgin Islands. A preliminary assessment. J coast Res 8:33-48

Isdale P (1984) Fluorescent bands in massive corals record centuries of coastal rainfall. Nature 310:578-579

Jokiel PL, Hunter CL, Taguchi S, Watari L (1993) Ecological impact of a freshwater 'reef kill' in Kaneohe Bay, Oahu, Hawail. Coral Reefs 12:177-184

King B, Wolanski E (1991) Coastal dynamics along a rugged coastline. In: Prandle D (ed) Dynamics and exchanges in estuaries and coastal zone. Springer-Verlag, New York, p $577-598$

Mayer AG (1918) Ecology of the Murray Island coral reef. Papers from the Department of Marine Biology. Carregie Inst Wash Publ 213:1-48

Muthiga NA, Szmant AM (1987) The effects of salinity stress on the rates of aerobic respiration and photosynthesis in the hermatypic coral Siderastrea siderea. Biol Bull 173:539-551

Orr AP (1933) Physical and chemical conditions in the sea in the neighbourhood of the Great Barrier Reef. Brit Mus Great Barrier Reef Exped. 1928-29. Sci Rept (3):37-86

Peters EC, Yevich PP (1989) Histopathogy of Ceriantheopsis americanus (Cnidaria: Ceriantharia) exposed to Black Rock Harbor dredge spoils in Long Island Sound. Dis aquat Org 7:137-148

Porter JW (1976) Autotrophy, heterotrophy, and resource partitioning in Caribbean reef-building corals. Am Nat $110.731-742$

This article was submitted to the editor
Rainford EH (1925) Destruction of the Whitsunday Group fringing reef. Aust Mus Mag 2:175-177

Risk MJ, Van Wissen FA, Beltran JC (1992) Sclerochronology of Tobago corals: a record of the Orinoco. Proc 7th Int Coral Reef Symp, Guam 1:156-161

Rogers CS (1979) The effect of shading on coral reef structure and function. $\mathrm{J}$ exp mar Biol Ecol 4:269-288

Rogers CS (1983) Sublethal and lethal effects of sediments applied to common Caribbean Reef corals in the field. Mar Pollut Bull 14:378-382

Sokal RR, Rohlf FJ (1995) Biometry. The principles and practice of statistics in biological research. Freeman WH, New York

Stafford-Smith MG (1993) Sediment-rejection efficiency of 22 species of Australian scleractinian corals. Mar Biol 115: $229-243$

Stoddart DR (1969) Ecology and morphology of recent coral reefs. Biol Rev 44:433-498

Van Woesik R (1991) Immediate impact of the January 1991 floods on the coral assemblages of the Keppel Islands. Great Barrier Reef Marine Park Authority Research Publication No 23, Townsville

Van Woesik R, Ayling AM, Mapstone B (1991) Impact of tropical cyclone 'Ivor' on the Great Barrier Reef, Australia. J coast Res $7(2): 551-558$

Williams EH Jr, Bunkley-Williams L (1990) The world-wide coral reef bleaching cycle and related sources of coral mortality. Atoll Res Bull 335:1-71

Wolanski E, van Senden D (1983) Mixing of Burdekin River flood waters in the Great Barrier Reef. Aust J mar Freshwat Res 34:49-63

Woodley JD, Chornesky EA, Clifford PA, Jackson JBC, Kaufman LS, Knowlton N, Lang JC, Pearson MP, Porter JW. Rooney MC, Rylaarsdan KW, Tunnicliffe VJ, Wahle CM, Wulff JL, Curtis ASG, Dallmeyer MP, Jupp BP, Koehl MAR, Neigel J, Sides EM (1981) Hurricane Allen's impact on Jamaican coral reefs. Science 214:749-755

Yonge CM, Nichools AG (1931) Studies on the physiology of corals. IV. The structure, distribution and physiology of zooxanthellae. Rep Gt Barrier Reef Exped 1:177-211

Manuscript first received: November 14, 1994

Revised version accepted: June 6, 1995 